The future Journal of Biology

2019;2:1-15

\title{
NOVEL ROLE OF 6-N-PENTYL-6H-PYRAN-2-ONE PRODUCED BY Trichoderma harzianum IN HYDROPONIC SYSTEM
}

\author{
Rateb Mostafa ${ }^{1}$ and Nosir Walid ${ }^{2}$
}

1. Department of Chemistry, Faculty of Pharmacy, Sohag University, Egypt.

2. Department of Horticulture, Faculty of Agriculture, Zgazig University, Egypt

\section{RESEARCH PAPER Accepted: 17 April 2019 published online: 26 June 2019}

\begin{abstract}
Secondary metabolites play a pivotal role in the antagonistic activities of some biocontrol species of Trichoderma sp. T. harzianum used previously as biological control agent against different pathogens. In this work, the effect of $F$. oxysporum f. sp. gladioli on the major secondary metabolites secreted by biocontrol strain of $T$. harzianum in Potato Dextrose Broth (PDB) cultures were investigated and quantified; followed by investigating the effect of the previous microorganisms on T. harzianumsecondary metabolites secreted in Gladiolus grandiflorus corms tissues under controlled conditions. Thin Layer Chromatography (TLC), Liquid chromatography Mass spectroscopy (LC/MS), and Nuclear Magnetic Resonance (NMR) techniques were used in this study to determine the major secondary metabolites. This is the first report recording the isolation, characterization and quantification of 6-n-pentyl-6H-pyran-2-one (6PP) and harzianic acid (HA) from the treated corms with T. harzianum. The secreted amounts from both metabolites were increased in the pre treated corms with T. harzianum followed by infection with $F$. oxysporum f. sp. gladioli. Results provided better understandings of the interaction mechanism between $T$. harzianum, $F$. oxysporum f. sp. gladioli which could be used in the future in different gene expression studies and will help in using them as bio fertilizers in biocontrol field.
\end{abstract}

Key words: Hydroponic, 6-n-pentyl-6H-pyran-2-one, Harzianic acid, Trichoderma harzianum.

\section{INTRODUCTION}

Hydroponic culture became the new modern agricultural technology this years; however the spreading of pathogens considers the major problem especially in closed system technique (Nosir, et al 2009). In recent years there has been growing interest in the potential use of microbial metabolites as agrochemicalsas an alternative to chemical fungicides. Microbial metabolites may help overcome problems associated with resistance of pathogenic fungi to fungicides and are generally more biodegradable and environmentally friendly than their synthetic counterparts (Tanakaand Mura, 1993). A wide range of antibacterial and antifungal secondary metabolites has been characterised from fungi, including from Trichoderma spp. (Vey et al., 2001). The correlation

Correspondent Author: Walid Nosir

w.nosir@gmail.com between the production of antimicrobial metabolites by biological control agents and the effectiveness of Biological control agents (BCA) preparations in vivo is still a matter of conjecture.

Trichoderma species are amongst the most common soil-borne fungi and well-known to have biological control capacity against soil-borne plant pathogens (Harman et al., 2004). Trichoderma spp. interacts simultaneously with plants and other microorganisms in the rhizosphere, including fungal pathogens. Moreover, they are useful model microorganisms in studies of complex multitrophic plant-microorganism interactions. Modes of action of Trichoderma spp. against pathogens include the

ISSN:2572-3006(Print)2572-3111(Online)

http://www.futurejournals.org 
The future Journal of Biology 2019;2:1-15

production of antifungal compounds, direct parasitism or inhibition of pathogen growth, cell wall-lytic enzyme activity (Benítez et al. 2004; Lorito et al., 1998), competition for nutrients (Chet 1987) and, as determined more recently, induction of systemic and localized resistance in the plant (Harman et al., 2004; Reino et al., 2008).

Secondary metabolites are a heterogeneous group of natural compounds that are considered to aid the producing organism in survival and basic functions, such as competition, symbiosis, metal transport and differentiation (Demain and Fang, 2000).

Species of Trichoderma are well-known producers of secondary metabolites with antibiotic activity (Howell, 2004; Demain and Fang, 2000; Ghisalberti and Sivasithamparam, 1998). The natural products produced by Trichodermaspp.vary in relation to (1) the specific compound, (2) the isolate and the species of Trichodermainvolved (3) the presence of other microorganisms in the niche and (4) the balance between elicited biosynthesis and biotransformation rates of the metabolites (Vinale $\boldsymbol{e t}$ al., 2009). Secondary metabolites secreted by Trichoderma spp. include volatile and non-volatile antifungal substances, such as 6-n-pentyl-6H-pyran-2one (6PP), gliotoxin, viridin, harzianopyridone, harziandione and peptaibols (Reino et al., 2008). The activities of these metabolites against soilborne plant pathogens have long been studied (Ghisalberti and Sivasithamparam, 1998). Production of secondary metabolites is considered an important factor in biological control, although the mechanisms of action of these compounds in soil and plants are not yet fully elucidated (Demain and Fang, 2000).

The involvement of secondary metabolites produced by Trichoderma spp. in the activation of plant defence mechanisms and the regulation of plant growth was recently investigated, using tomato and oil-seed rape seedlings treated with harzianolide and 6PP isolated from T. harzianum, followed by infection with spore suspensions of Botrytis cinerea and Leptosphaeriamaculans, respectively. In both host plant species, a reduction in disease symptoms was observed, particularly on 6PP-treated plants. Moreover, application of the metabolites lead to overexpression of pathogenesis-related (PR) proteins in treated plants (Vinale et al., 2008).

Antibiosis assays demonstrated that secondary metabolites produced by $T$. harzianum (azaphilone, butenolide, harzianolide, harzianopyridone) had different activities towards

Rhizoctoniasolani, Pythiumultimum and Gaeumannomycesgraminis var. triticiin in vitro tests, suggesting that individual compounds had specific modes of action (Vinale $\boldsymbol{e t}$ al, 2006). The level of production of metabolites by Trichoderma spp. varies according to the target pathogen and the strain of Trichoderma in use. Increased concentrations of 6PP were secreted by $T$. harzianumin interactions with Botrytis cinerea, but the absolute concentration produced was related to the isolate of Trichoderma used (Cooney and Lauren, 1998). There are no reports in the literature on the effects of $F$. oxysporum f. sp. gladioli on $T$. harzianum natural products.

The aims of the work presented here were to develop an improved understanding of the roles of major secondary metabolites produced by $T$. harzianum in the interaction between $T$. harzianum, $F$. oxysporum f. sp. gladioli.

\section{RESULTS}

\section{Isolation and chemical characterization of major compounds}

Accurate mass analysis of compound 1, with $[\mathrm{M}]+$ at $\mathrm{m} / \mathrm{z} 167.1$ (Figure 1) suggested the formula 
The future Journal of Biology 2019;2:1-15

$\mathrm{C}_{10} \mathrm{H}_{14} \mathrm{O}_{2}$, and thus 4 degrees of unstauration. The ${ }^{13} \mathrm{C}$ NMR spectrum indicated a pyrone carbon at $\delta 163.0$, an oxygenated carbon at $\delta 167.0,3$ olefinic carbons ( $\delta 105-140), 4$ methylene carbons ( $\delta 20-35)$ and one methyl carbon at $\delta 14.0$ (Figure $2 \& 3$ ). The UV spectrum of compound 1 had a peak at $336 \mathrm{~nm}$ (Figure 4). Database searches indicated that the major unknown compound was 6-n-pentyl-6H-pyran-2-one (6PP). 6PP was the most secondary metabolite in liquid cultures of $T$. harzianum, with a yield of 0.356 mg. $1^{-1}$.

The mass spectrum of compound 2 showed a molecular ion $[\mathrm{M}]^{+}$at $\mathrm{m} / \mathrm{z} 366.19$ (Figure 5) corresponding to the molecular formula $\mathrm{C}_{19} \mathrm{H}_{27} \mathrm{NO}_{6}$. The structure of compound 2 was deduced from ${ }^{1} \mathrm{H}$ NMR and ${ }^{13} \mathrm{C}$ NMR spectral data (Figures 6 and 7). The ${ }^{1} \mathrm{H}$ NMR in $\mathrm{CD}_{3} \mathrm{OD}$ exhibited a doublet at 7.09 ppm $(2-\mathrm{H}, 7=15 \mathrm{~Hz})$, an olefinic proton at $7.53 \mathrm{ppm}$ (3-H) and overlapping signals cantered at $6.39 \mathrm{ppm}$ (4-H and 5-H). Analysis of the ${ }^{13} \mathrm{C}$ NMR spectrum of compound 2 suggested that compound 2 had a carboxyl group (178.6 ppm). The UV spectrum of harzianic acid had a peak in absorbance at $259 \mathrm{~nm}$ (Figure 8). Database searches and direct comparison with mass and ${ }^{1} \mathrm{H}$ and ${ }^{13} \mathrm{C}$ NMR spectral data identified the compound as harzianic acid.

\section{Production of 6PP and harzianic acid in liquid cultures}

T. harzianum produced $0.085 \mathrm{mg} / \mathrm{ml} 6 \mathrm{PP}$ in the liquid medium. In dual cultures with $T$. harzianum and $F$. oxysporum f. sp. gladioli, however, 0.125 $\mathrm{mg} / \mathrm{ml}$ was recovered. Harzianic acid concentrations were nearly doubled in dual cultures of $T$. harzianum and $F$. oxysporum f. sp. gladioli, based on peak heights recorded on HPLC.

\section{Production of 6PP and harzianic acid in Gladiolus corms}

In gladiolus corms treated with T. Harzianum alone, $0.058 \mathrm{mg} . \mathrm{g}^{-1}$ 6P was found; in contrast, corm tissues treated with T.harzianum followed by inoculation with $F$. oxysporum f. sp. gladioli had 6fold greater concentrations of $6 \mathrm{PP}\left(0.354 \mathrm{mg}^{\mathrm{g}} \mathrm{g}^{-1}\right)$ were observed Harzianic acid concentrations were nearly double in $T$. harzianum-treated and $F$. oxysporum f. sp. gladioli inoculated corms, compared with corms treated with $T$. Harzianum alone. Concentrations of HA were estimated based on peak heights recorded on HPLC.

\section{Biological activity of 6 PP}

F. oxysporum f. sp. gladioli growth was completely inhibited by 6PP at all concentration from $10 \mu \mathrm{g}$ to $100 \mu \mathrm{g}$ on PDA in Petri dishes.

\section{Effect of 6PP on Gladiolus growth in Hydroponic cultures}

Gladiolus plant that coated by 10ppm of 6PP germinated 3 days earlier than the untreated and the flower harvest yield was $35 \%$ more than the control in flower fresh weight. Flower stalk diameters in the treated corms with 6PP were $29.5 \%$ taller than the control. The bullet numbers were $46 \%$ more than the untreated. (data not shown).

\section{DISCCUSION}

The work reported here confirmed the production of antibiotic compounds by $T$. harzianum within corm tissues of Gladiolus infected with $F$. oxysporumf.sp. gladioli. Hiterhto, the ability of Trichodermaspp to secrete antibiotic compounds in infection courts had not been confirmed (Whipps, 2001). Distinguishing the antibiotics secreted in the presence of fungal diseases will help in understanding the mechanisms of action utilized by $T$. harzianum in the biological control of plant pathogens. 
The future Journal of Biology

2019;2:1-15

The antagonistic mechanisms used by Trichodermaare clearly rather complex, and include competitive effects during spore germination and mycelial growth, mediated by the secretion of extracellular enzymes, such as chitinases (Cruz et al. 1992), $\beta$-glucanases (Lorito et al. 1996) and proteinases (Geremia $\boldsymbol{e t}$ al. 1993), as well as the secondary metabolite produced (Sivasithamparam and Ghisalberti 1998).

The aim of this work was to develop further understanding of the roles of secondary metabolites produced by $T$. harzianum during intereactions with $F$. Oxysporum f.sp. gladioli in interactions with corm tissues of Gladiolus grandiflorus tissues. The role of antibiotics produced by Trichoderma in biological control remains a matter of conjecture. Although certain metabolites with antibiotic activity may be major factors in the biocontrol activity of a given isolate of the fungus, this may not be the case for other isolates (Harman 2000). The detection of 6PP as the most abundant antifungal compound produced by $T$. harzianum $\mathrm{T} 22$ in the presence or absence of $F$. oxysporum f. sp. gladioli suggest that this metabolite may be of interest in terms of bio-fungicide potential. Similar results were reported by Vinale et al. (2008), who recorded 6PP as a major secondary metabolite secreted by $T$. harzianum, with activity against $B$. cinereaon tomato and L. maculatnson oil seed rape. The results obtained in the present work support the suggestion that antibiotic production during saprophytic and antagonistic growth of $T$. harzianum could be involved, in concert with other mechanisms, in the inhibitory interaction with plant pathogens (Howell, 2004).

F. oxysporumf. sp. gladioli showed greater sensitivity to 6PP than previously reported for Rhizoctoniasolaniand a different $F$. oxysporum (Scarselletti and Faull, 1994). In the earlier work, addition of $300 \mu \mathrm{g} / \mathrm{ml}$ 6PP to Potato Dextrose medium caused a $69.6 \%$ growth reduction in $R$. solani and a $31.7 \%$ reduction in $F$. oxysporum after 2 days, and completely inhibited the germination of Fusarium spores at a concentration of $450 \mu \mathrm{g} / \mathrm{ml}$. Although, $B$. cinerea metabolized $6 \mathrm{PP}$ in agar and on liquid cultures (Cooney and Lauren, 1998). Moreover, a strong relationship was found between the production of 6PP and the antagonistic ability of by $T$. harzianum in vitro and control of B. cinerea rots in stored kiwi fruits has also been investigated by Poole et al. (1998).

This work findings described in this manuscript confirms Vinale et al., (2008) findings which reveal that the secondary metabolite, 6PP excreted by the antagonistic fungus T. harzianum not only interfered with the pathogenic fungus Botrytiscinerea or Leptosphaeriamaculans by inhibiting the mycelial growth and conidia production and germination but by promoting the plant growth and increased the plant resistance against diseases that could be one of the mechanisms T. harzianum used to stimulate plant growth. Ghisalberti and Sivasithamparam (1998) previously suggested that some secondary metabolites were directly involved in T. harzianum-plant interactions, and that the compound 6PP may act as an auxin-like compound and/or may act as an auxin inducer.

The chemical structures of the Trichoderma metabolites isolated in the present work suggests two different possible mechanisms of action. These low molecular weight, non-polar, 6PP and harzianic acid, are produced in high concentrations in the soil environment, and have a relatively long range of influence on the microbial community. In contrast, a short distance effect may results from the presence of polar metabolites and peptaibols acting in close proximity to the producing hyphae (Lorito et al.,1996).

$6 \mathrm{PP}$ was recently reported as a plant growth promoting metabolite from Trichodermaharzianum 
The future Journal of Biology 2019;2:1-15

(Vinale et al., 2009), as coating seed of Brassica napus with the compound lead to increases in stem length, compared to control seed. In the same work harzianic acid at concentrations as low as $1-10 \mu \mathrm{g} \mathrm{L}$ 1 showed inhibitory activity against Pythiumirregulare, Sclerotiniasclerotiorum and Rhizoctoniasolani .

This work findings and Vinale et al., (2009) findings help in opening a new way in studying the role of metabolites secreted from biocontrol agents in the glasshouse or field studies as the used of use of new products based on biocontrol agents and/or their metabolites for disease control is one of the most promising ways to reduce the dependence on synthetic pesticides in agriculture. Various biocontrol agents have been registered and are available as commercial products, including strains belonging to the genus Trichoderma but according to our knowledge there are no registered bio- products from trichoderma metabolites, although Fungal strains of the genus Trichoderma are well-known producers of secondary metabolites with antibiotic activity. Their production varies in relation to (i) the specific compound; (ii) the strain and the species; (iii) the presence of other microbes; and (iv) the balance between elicited biosynthesis and biotransformation rtes (Harman, 2004).

Understanding of the roles played by the secondary metabolites of $T$. harzianum may further the development of new, targeted biopesticides and bio-fertilizers based on these naturally occurring compounds. Such compounds may be used as elicitors of plant defense mechanisms, direct toxins to the pathogens and plant growth stimulants.

This is the first work to report the production of secondary metabolites by $T$. harzianum in Gladiolus corms infected with $F$. oxysporum f. sp. Gladioli in hydroponics. The results improve understanding of the interaction between $T$. harzianum and $F$. oxysporum f. sp. gladioli in the host plant tissues. Further studies on the range of antibiotic compounds produced by $T$. harzianum and the efficiency of these compounds in plant-pathogenantagonist inereactions are required to further increase understanding of the mechanism of action of these bioactive compounds under field conditions.

\section{Experimental}

\section{Preparation of pathogen inoculum}

The inoculum was prepared using an isolate of $F$. oxysporum f. sp. gladioli isolated in this work from a purchased Gladiolus corm. The culture was maintained on PDA (Oxoid, Basingtoke, Hants, UK) at $22^{\circ} \mathrm{C}$ and routinely sub-cultured at 15 day intervals. Subcultures of $F$. oxysporum f. sp. gladioli were prepared by inoculating PDA with $1 \mathrm{~cm}$ diam. disks of colonized PDA plus mycelium, cut from the edge of an actively growing, 7 day old colony.

\section{Preparation of antagonist inocula}

Trichodermaharzianum isolate $\mathrm{T} 22$, used as a fungal antagonist in this study, was obtained as freezedried spores from CentraalbureauvoorSchimmelculturen CBS, The Netherlands.One $\mathrm{ml}$ sterilized distilled water was added to the freeze dried spores and $0.1 \mathrm{ml}$ of spore suspension used to inoculate fresh PDA in $9 \mathrm{~cm}$ diam. Petri dishes. Cultures were sealed with Parafilm (Alpha Laboratories, Hampshire, UK)., and incubated at $22^{\circ} \mathrm{C}$ with routine sub-culturing at 15 day intervals. Subcultures of $T$. harzianum were prepared by inoculating PDA with $1 \mathrm{~cm}$ diam. disks of colonized PDA plus mycelium, cut from the edge of an actively growing, 7 day old colony.Spore suspensions were obtained by flooding 7 day old cultures on PDA with $5 \mathrm{ml}$ sterile distilled water, gently agitating the surface with a wire loop and passing the suspension through two layers of washed sterile muslin directly into $50 \mathrm{ml}$ 
The future Journal of Biology 2019;2:1-15

centrifuge tubes. Spore suspensions were centrifuged at $3000 \mathrm{rpm}(1700 \times \mathrm{g})$ in a Thomson-MSE Mistral bench top centrifuge for $10 \mathrm{~min}$. Following rinsing the spore pellets twice in sterile distilled water, with repeated centrifuging (as above); spore concentrations were adjusted to $4.00 \times 10^{8}$ spores $\mathrm{ml}^{-1}$ using repeated hemocytometer counts under a light microscope at a magnification of $\times 40$.

\section{Inoculation with antagonists}

Gladiolus corms, variety Big flower GT01 size 14 (Tylore Bulb, Co., The Netherlands) were surface sterilized in $20 \% \mathrm{NaOCl}$ for $20 \mathrm{~min}$ before rinsing in running tap water for 6 hours, followed by 3 rinses in sterilized distilled water. Corms were submerged in $T$. harzianumor A. migulanus spore suspensions for $30 \mathrm{~min}$. For the interaction treatments, corms were suspended in the antagonist suspension and gently blotted dry on sterilized Whatman, No 3 filter paper under aseptic conditions in a laminar flow cabinet. The combination between T. harzianum and A. migulanus was prepared by mixing equal volumes of antagonist suspensions in a $2000 \mathrm{ml}$ beaker, immersing surface sterilized corms in the mixed suspension for $30 \mathrm{~min}$ and inoculating with the pathogen, as described below. Control corms were immersed in sterilized distilled water for the same length of time.

\section{Inoculation with Fusarium oxysporumf. sp. gladioli}

The Gladiolus corms inoculated with antagonists were subsequently inoculated with $F$. oxysporum f. sp. gladioli by removing a $10 \mathrm{~mm}$ diam., $5 \mathrm{~mm}$ deep piece of tissue from the surface of the corm and replacing it with a plug of PDA plus fungal mycelium of the same dimensions. The corms after inoculation were incubated in $22^{\circ}$ in laminar flow Lesion areas developing on inoculated corms were measured 3 days after treatment to estimate the efficiency of the antagonists before collecting the samples for analysis.

\section{Antagonist and pathogen culture}

T. harzianum alone; T. harzianum $+F$. oxysporum f. sp. gladioliT. harzianum treatments (1 L each); was cultured and the secondary metabolites extracted using the method of Vinale et al., (2006; 2008). Two $10 \mathrm{~mm}$ diameter plugs of $T$. harzianum T22 were taken from the actively growing margin of cultures on potato dextrose agar (PDA; Oxoid, Basingtoke, Hants, UK) cultures and inoculated into $250 \mathrm{ml}$ conical flasks containing $100 \mathrm{ml}$ of full strength potato dextrose broth (PDB; Oxoid, Basingtoke, Hants, UK).

The same technique was used in dual cultures of $T$. harzianum and F. oxysporum f. sp. gladioli, the previous method was used, with addition of two 10 mm diameter plugs of $F$. oxysporum f. sp. gladioli into the same flask with $T$. harzianum. Cultures were incubated on rotary shaker at $220 \mathrm{rpm}$ (Gallenkamp, Rhys Scientific Ltd, UK) for 15 days at $22^{\circ} \mathrm{C}$.

\section{Inoculation of Gladiolus corms}

Gladiolus corms were inoculated with $T$. harzianum and A. migulanus, followed by inoculation with $F$. oxysporum f. sp. gladioli. The inoculated corms were incubated over moistened filter paper (Whatman No 1) with sterilized distilled water in plastic containers $(22 \times 12 \times 32 \mathrm{~cm})$ at $22^{\circ} \mathrm{C}$. The filter papers were moistened daily under aseptic conditions.

\section{Extraction and quantitation of secondary metabolites}

The inoculated corms were frozen in liquid $\mathrm{N}$ and homogenized into fine powder using a hilled mortar and pestle. Aliquots $(20 \mathrm{~g})$ of the powder were extracted exhaustively with ethyl acetate (EtOAc) at room temperature for 3 times. The combined organic fraction was dried over $\mathrm{Na}_{2} \mathrm{SO}_{4}$ and evaporated under reduced pressure at $35^{\circ} \mathrm{C}$. The residue was taken up in $5 \mathrm{ml}$ of EtOAc and subjected flash column 
The future Journal of Biology

2019;2:1-15

chromatography on a600 x $30 \mathrm{~mm}$ column of Kieselgel 60 A, $0.40-63$ micron (Merck, 50 g). The column was eluted in aEtOAc: hexane $(1: 1 \mathrm{v} / \mathrm{v})$ gradient. Fractions showing similar thin-layer chromatography (TLC) using aluminium backed Merck Kieselgel 60 F254 plates, 0.2 mm thickness. Fractions of $20 \mathrm{ml}$ were collected and subjected to analytical TLC. Fractions showing similar TLC profiles based on UV detection at $254 \mathrm{~nm}$ were combined and purified compounds subjected to mass analysis using liquid chromatography-mass spectrometry (LC/MS; Thermo Instruments.) Further purification of the flash column chromatography residue from each treatment was carried out using high performance liquid chromatography (HPLC) on a C18 HD analytical column (250 mm x $4 \mathrm{~mm}$; Agilent, USA), with an Agilent Series 1100 LC pump (Agilent, USA), coupled to an LC 90 UV spectrophotometer (Jasco International Co. Ltd.). Samples (100 $\mu$ l) were eluted at room temperature in a linear gradient of $20-$ $80 \%$ acetonitrile in acidified water $(0.1 \%$ trifluoroacetic acid; Sigma- Aldrich) over $30 \mathrm{~min}$ Purified compounds were characterized and identified using accurate mass analysis (LC/ MS). High resolution mass spectral data were obtained using a Thermo Instruments MS system (LTQ XL/ LTQ Orbitrap Discovery) coupled to a Thermo Instruments HPLC system (Accela PDA detector, Accela PDA autosampler and Accela Pump).

Compounds were identified, based on MS and NMR data by comparison with the Beilstein database (2010) and directly with mass and ${ }^{1} \mathrm{H}$ and ${ }^{13} \mathrm{C}$ NMR spectral data in the literature (Dunlop et al., 1989). ${ }^{1} \mathrm{H}$ and ${ }^{13} \mathrm{C}$ NMR analysis were done on Varian 400MHz NMR spectrophotometer.

The filtered broth cultures of each treatment (1 L each); T. harzianum alone; T. harzianum $+F$. oxysporum f. sp. gladioli were extracted with ethyl acetate (3 x $500 \mathrm{ml}$ each). Cultures were filtered under vacuum through Whatman No. 4 filter paper (Brentford, UK) and the filtrates stored at $2^{\circ} \mathrm{C}$ for 24 h. Filtrates were extracted three times in $500 \mathrm{ml}$ EtOAc, organic phases combined and rotary evaporated (BuchiRotavapor R-200, Switzerland) to dryness under reduced pressure at $40^{\circ} \mathrm{C}$. The residue obtained from $T$. harzianum was brown $(1.5 \mathrm{~g}) ; T$. harzianum $+F$. oxysporum f. sp. gladioli reddishbrown $(0.869 \mathrm{~g})$, and $T$. harzianum $+F$. oxysporum $\mathrm{f}$. sp. gladioli + A. migulanus yellow-brown $(0.475 \mathrm{~g})$. Residues were re-dissolved in $3 \mathrm{ml}$ methanol each and further purified by flash column chromatography, using isocratic elution in EtOAc: hexane $(2: 1 \mathrm{v} / \mathrm{v})$, as described above.

\section{Biological activity of 6PP}

The purified 6PP was tested against growth of $F$. oxysporumf. sp. gladioli using the method of Vinaleet al. (2008). Discs of fungal mycelium on PDA, $10 \mathrm{~mm}$ in diam., were placed at the centre of 90 $\mathrm{mm}$ diam. Petri dishes containing fresh PDA. Test compounds were added in a $10 \mu \mathrm{l}$ drop of methanol containing $10,20,50$ and $100 \mu \mathrm{g}$ of the compound per plug of $F$. oxysporum f. sp. gladioli. Cultures were incubated at $25^{\circ} \mathrm{C}$ for 7 days. Pathogen growth was measured daily. Each treatment consisted of three replicates and the experiment was repeated twice.

\section{Effect of 6PP on Gladiolus growth in Hydroponic cultures}

Gladiolus corms were grown hydroponically as described by Nosir $\boldsymbol{e t} \boldsymbol{a l}, \mathbf{2 0 0 9}$. The corms were treated with 10ppm solution of 6PP in Arabic gum and kept for drying at room temperature.

\section{REFERENCES}

Benítez, T.; Rincón, A.M.; Limón, M.C. and Codón, A. C. (2004). Biocontrol mechanisms of 
The future Journal of Biology

2019;2:1-15

Trichoderma strains. International Microbiology, 7:249-260.

Chet, I. (1987). Trichoderma - application, mode of action, and potential as biocontrol agent of soilborne plant pathogenic fungi. In Innovative Approaches to Plant Disease Control ed. Chet, I. pp. 137-160. New York: John Wiley \& Sons.

Claydon, N.; Allan M.; Hanson J. R. and Avent A.G. (1987). Antifungal alkyl pyrones of Trichodermaharzianum. Mycological research, 88:503-513.

Cooney, J.M. and Lauren, D.R. (1998). Trichoderma/ pathogen interactions: measurement of antagonistic chemicals produced at the antagonist/ pathogen interface using a tublar bioassay. Letters in Applied Microbiology, 27: 283-286.

Cruz, J.; Hidalgo-Gallego, A.; Lora, J.M.; Benitez, T.; Pintor- Toro, J.A. and Llobell, A. (1992). Isolation and characterization of three chitinases from Trichodermaharzianum. European Journal of Biochemistry, 206: 859-867.

Demain, A. L. and Fang, A. (2000). The natural functions of secondary metabolites. Advanced Biochemistry Engineering and Biotechnology, 69:139.

De meyer, G.; Bigirimana, J.; Elad, Y. and Höfte, M., (1998). Induced systemic resistance in Trichodermaharzianum T39 biocontrol of Botrytis cinerea. European Journal of Plant Pathology, 104: 279-286.

Dunlop, R.; Simon, A. and Sivasithmparam, K. (1989). An Antibiotic from Trichodermakoningii active against soil borne Plant Pathogens. Journal of Natural Products, 52:67-74.

Geremia, R.A.; Goldman, G.H.; Jacobs, D.; Ardiles, W.; Vila, S.B.; van Montagu, M. and Herrera-Estrella, A. (1993). Molecular characterization of the proteinase-encoding gene, prb1, related to mycoparasitism by Trichodermaharzianum. Molecular Microbiology, 8: 603-613.

Ghisalberti, E. L. and K. Sivasithamparam. (1998). Antifungal antibiotics produced by Trichoderma spp. Soil Biology and Biochemistry, 23:1011-1020.
Handelsman, J. and Stabb, E. V. (1996). Biocontrol of Soilborne Plant Pathogens. Plant Cell, 8:18551869.

Harman, G.E. (2000). Myths and dogmas of biocontrol: changes in perceptions derived from research on Trichodermaharzianum T-22. Plant Disease, 84: 377-393.

Harman, G.E.; Howell, C.R.; Viterbo, A.; Chet, I. and Lorito, M. (2004). Trichoderma speciesopportunistic, avirulent plant symbionts. Nature Review Microbiology, 2:43-56.

Howell, C.R. (2004). Mechanisms employed by Trichoderma species in the biological control of plant diseases: The history and evolution of current concepts. Plant Disease, 87: 4-10.

Lorito, M. (1998). Chitinolytic enzymes and their genes. In Trichoderma and Gliocladium, vol. 2 ed. Harman, G.E. and Kubicek, C.P. pp. 73-99. London: Taylor and Francis Ltd.

Lorito, M.; Farkas, V.; Rebuffat, S.; Bodo, B. and Kubicek, C.P. (1996). Cell wall synthesis is a major target of mycoparasitic antagonism by Trichodermaharzianum. Journal of Bacteriology, 178: 6382-6385.

Nosir, W.; McDonald, J. and Woodward, S. (2009). Interaction effect between Trichoderma harzianum and Aneurinobacillus migulanus against Fusarium oxysporum f. sp. gladioli on Trichoderma secondary metabolites. Oral presentation, International Mycology Congress 2010, Edinburgh, UK.

Poole P.R.; Ward B.G. and Whitaker, G. (1998). The effects of topical treatments with 6-pentyl-2pyrone and structural analogs on stem end postharvest rots in kiwi fruit due to Botrytis cinerea. Journal of Agriculture and Food Chemistry, 77:8186.

Reino, J.L.; Guerriero, R.F.; Herna`ndez-Gala, R. and Collado, I.G. (2008). Secondary metabolites from species of the biocontrol agent Trichoderma. Photochemistry Review, 7: 89-123.

Sivasithamparam, K. and Ghisalberti, E. L. (1998). Secondary metabolism in Trichoderma and Gliocladium. In: Kubiecek CP, Harman GE (eds) Trichoderma and Gliocladiumvol 1. Taylor and Francis, London, pp 139-191. 
The future Journal of Biology

2019;2:1-15

Scarselletti, R. and Faull, L. (1994). In vitro activity of 6-pentyl-a-pyrone, a metabolite of Trichodermaharzianum, in the inhibition of Rhizoctoniasolani and Fusariumoxysporum f. sp. lycopersici. Mycological Research, 98:1207-1209.

Tanaka, Y. and Ojmura, S. (1993). Agroactive compounds of microbial origin. Annual Review of Microbiology, 47: 57-87.

Vey, A.; Hoagland, R. and Butt, T. M. (2001). Toxic metabolites of fungal biocontrol agents. In Fungi as Biocontrol Agents; Butt, T. M., Jacskon, C., Magan, N., Eds.; CAB International: Wallingford, UK, pp 311-340.

Vinale, F.; Sivasithamparamb, K.; Ghisalberti, E.L.; Marra, R.; Barbetti, M.J.; Li, H.; Woo, S.L. and Lorito, M. (2008). A novel role for Trichoderma secondary metabolites in the interactions with plants. Physiological and Molecular Plant Pathology, 72: 8086.

Vinale, F.; Marra, R.; Scala1, F.; Ghisalberti, E.L.; Lorito, M. and Sivasithamparam, K. (2006). Major secondary metabolites produced by two commercial Trichoderma strains active against different phytopathogens. Letters in Applied Microbiology,43: 143-148.

Vinale, F.; Sivasithamparam, K.; Ghisalberti, E.L.; Mara, R.; Barbeti, M.J; Li, H.; Woo, S. L. and Lorito, M. (2009). A novel role for Trichoderma secondary metabolitesin the interactions with plants. Physiological and Molecular Plant Pathology, 72: 8086.

Whipps, J. M. (2001). Microbial interactions and biocontrol in the rhizosphere. Journal of Experimental Botany, 52: 487-511.

ISSN:2572-3006(Print)2572-3111(Online)

http://www.futurejournals.org 
The future Journal of Biology

2019;2:1-15

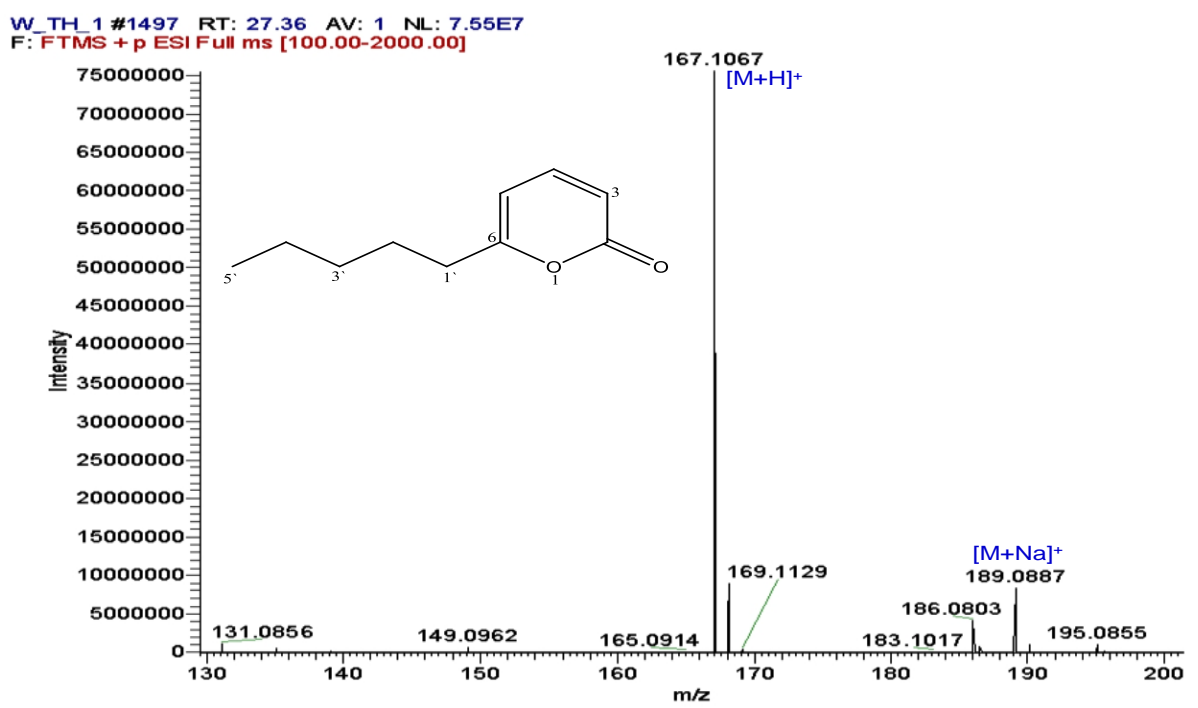

Fig. ( ): Mass spectrum of 6PP

Figure 1: Mass spectrum of compound 1.

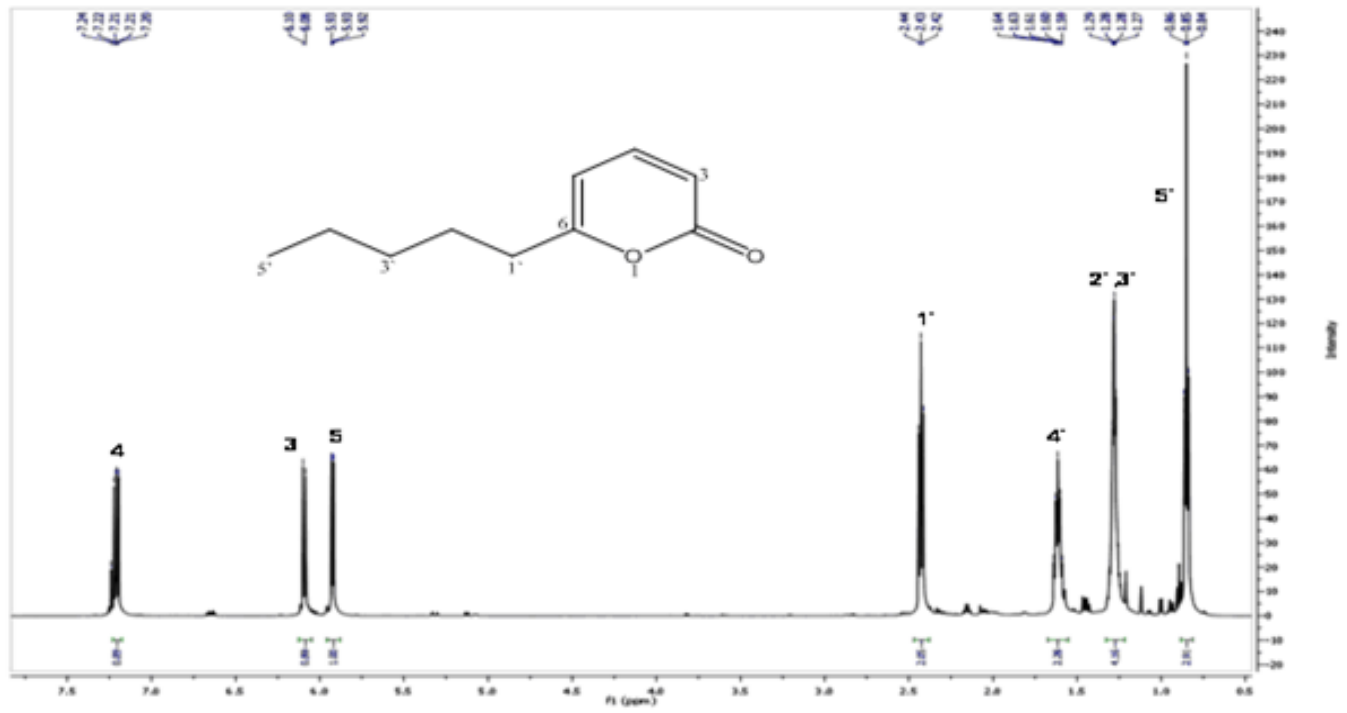

Figure 2: ${ }^{1} \mathrm{H}$ NMR spectrum of compound 1.

ISSN:2572-3006(Print)2572-3111(Online)

http://www.futurejournals.org 
The future Journal of Biology

2019;2:1-15

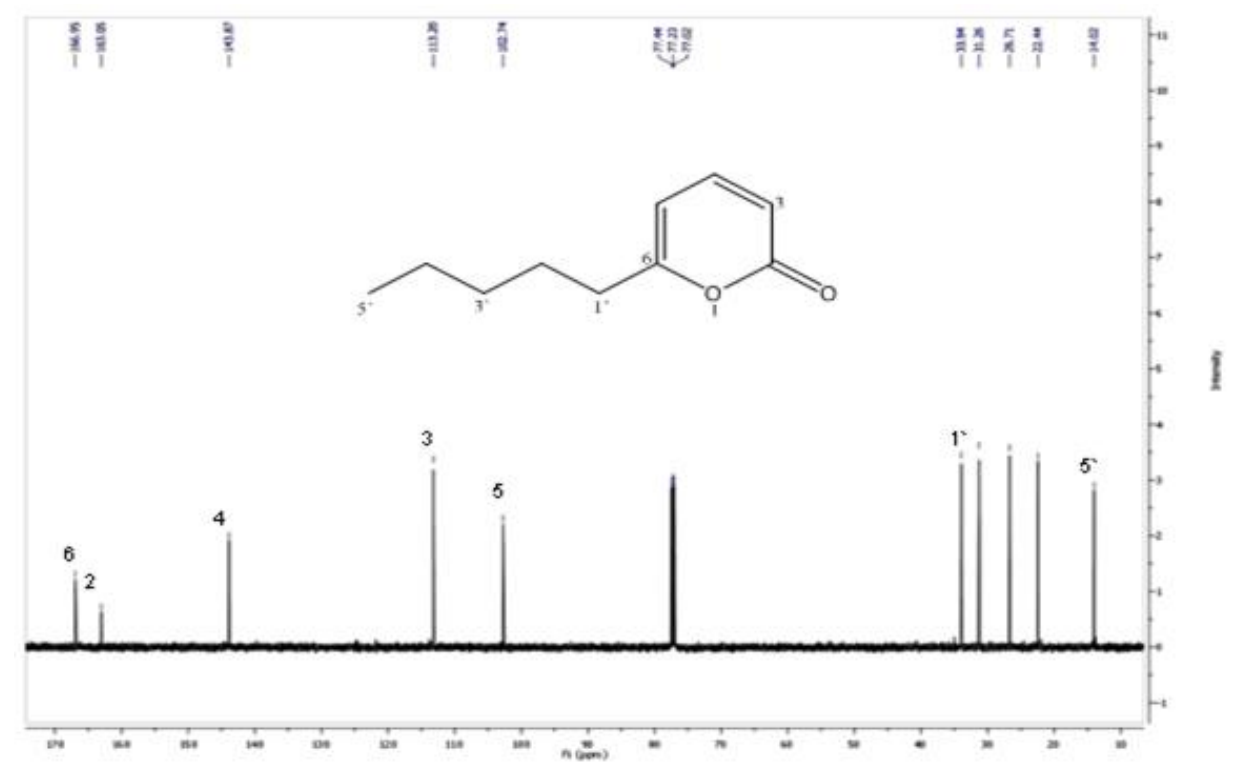

Figure 3: ${ }^{13} \mathrm{C}$ NMR spectrum of compound 1.

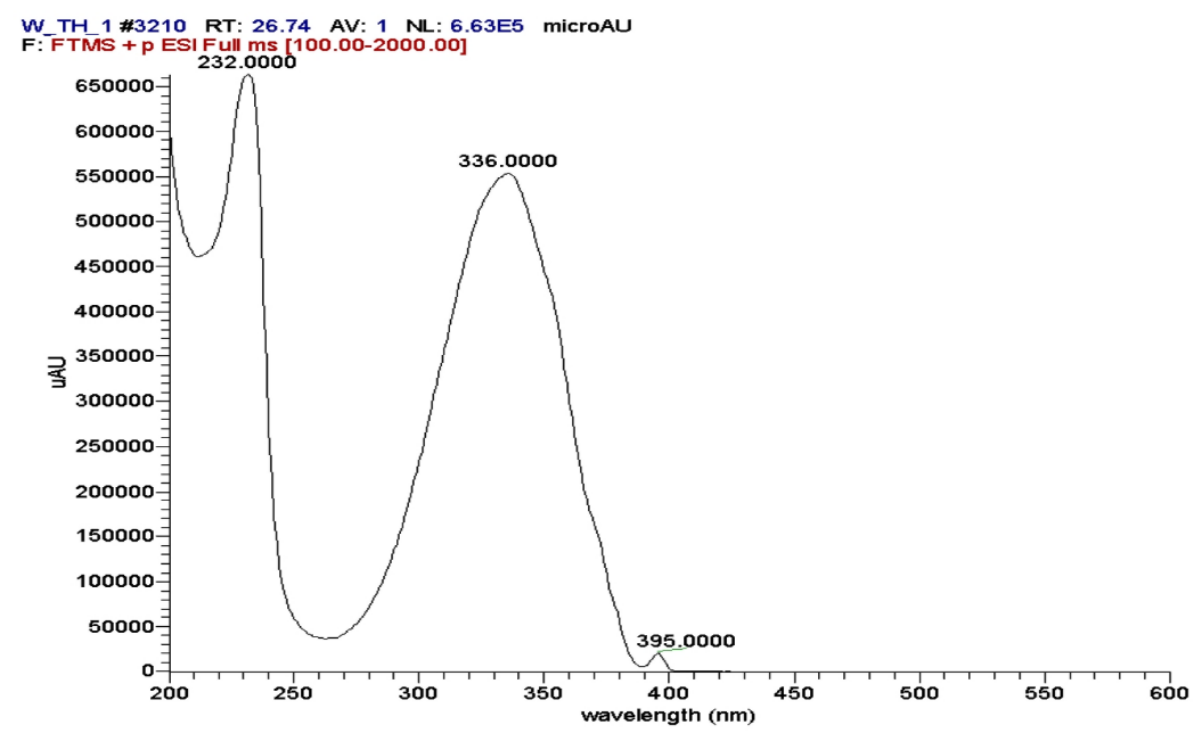

Figure 4: UV spectrum of compound 1.

ISSN:2572-3006(Print)2572-3111(Online)

http://www.futurejournals.org 
The future Journal of Biology

2019;2:1-15
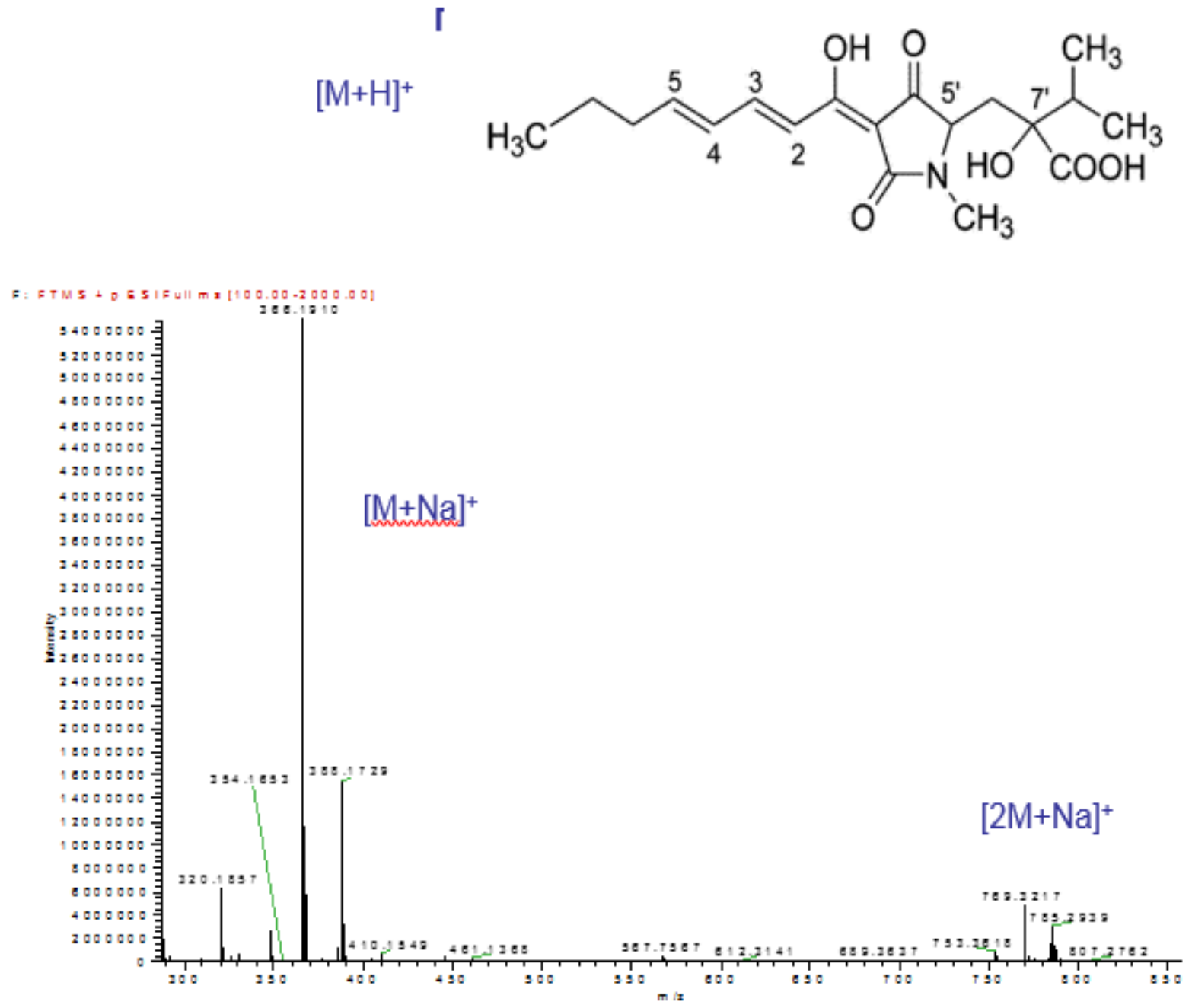

Figure5: Mass spectrum of compound 2.

ISSN:2572-3006(Print)2572-3111(Online)

http://www.futurejournals.org 
The future Journal of Biology

2019;2:1-15

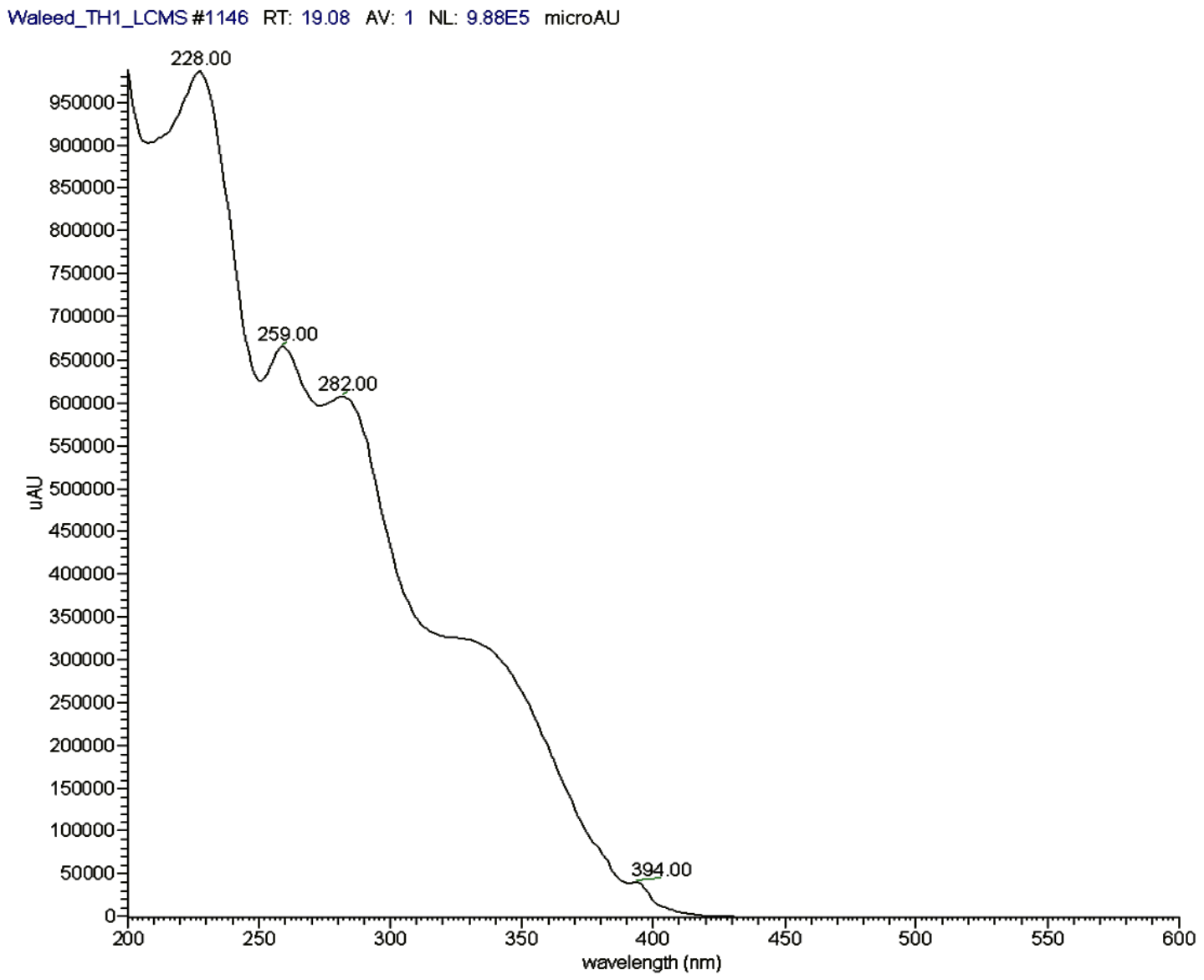

Figure 6: UV spectrum of compound 2.

ISSN:2572-3006(Print)2572-3111(Online)

http://www.futurejournals.org 
The future Journal of Biology

2019;2:1-15

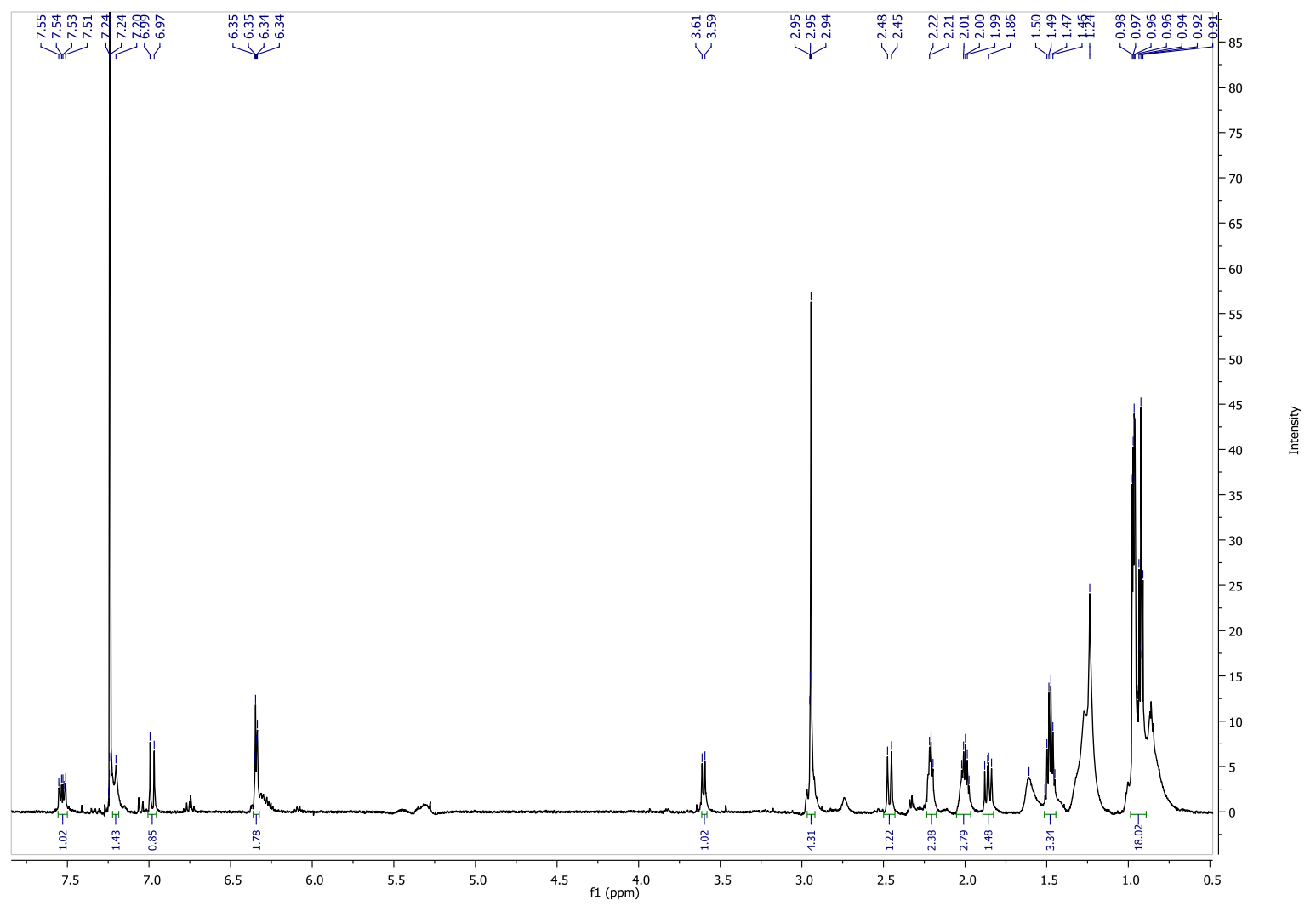

Figure 7: ${ }^{1} \mathrm{H}$ NMR spectrum of compound 2.

ISSN:2572-3006(Print)2572-3111(Online)

http://www.futurejournals.org 
The future Journal of Biology

2019;2:1-15

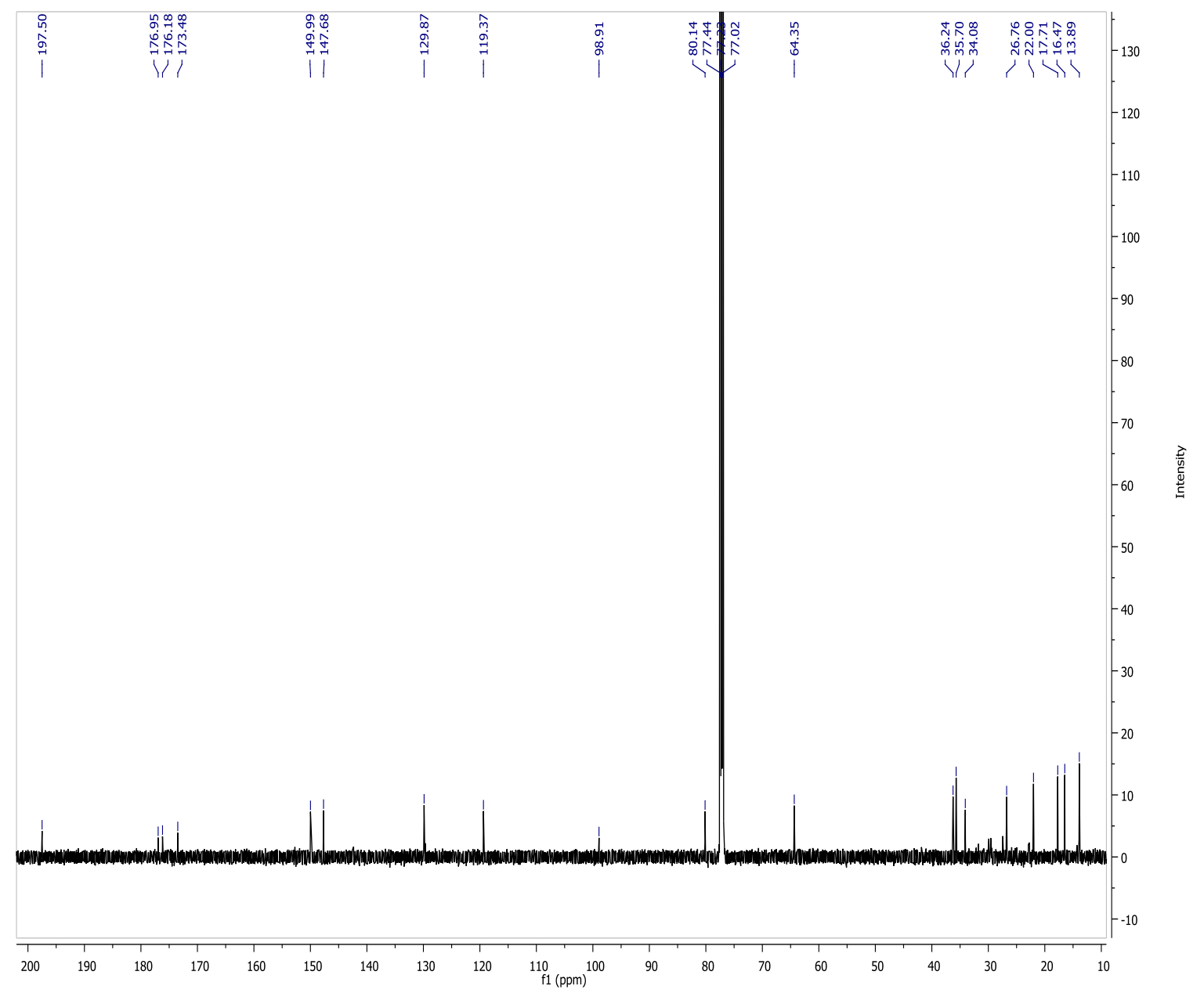

Figure 8: ${ }^{13} \mathrm{C}$ NMR spectrum of compound 2.

ISSN:2572-3006(Print)2572-3111(Online)

http://www.futurejournals.org 